\title{
Convince me you exist. An analysis of The Kurdistan Workers Party (PKK) court files
}

Convénceme que existes. Un análisis de los expedientes judiciales del Partido de los Trabajadores del Kurdistán (PKK)

Islam Sargi

University of Szeged - Hungary

Szeged, Hungary

iszeged509@gmail.com

\section{Abstract}

The end of empires and the rise of nation-states have transformed the way politics and societies operate and the modern sense of these changes, transformations, events, and situations. Language, culture, and memory are essential pillars of the nation-states' projects of creating a new society. The modern form of government, the nation-state, use history not only as a means of transmission but also as a means of building identity and memory. This study examines the case files of three critical names in the Kurdish movement and the history-based debates in their trials. By applying discourse analysis, we have shown how the Turkish state and The Kurdish Workers' Party used history as a tool to "prove" and "disprove" the existence of Kurds, the Kurdish language, and Kurdistan. While the judges imposed an evidence-based approach to history and denied the existence of Kurds, Kurdish and Kurdistan, the PKK members opposed the official thesis of the state and built their arguments more on the day-to-day realities of life. The study's main argument is that the official ideology uses history to prove and convey a message to the rest of society, whereas the defendants used it as a means of protest depending on the historical reality rather than history as a science. This study discusses that by using science to make examples of these members, the judges used history to prove the Kurds' non-existence, whereas the defendants implied history as a way of protesting the ruling authority.

Keywords: Trails; History; The Kurdish Workers Party

\section{Resumen}

El fin de los imperios y el surgimiento de los Estados-nación han transformado el funcionamiento de la política y las sociedades y el sentido moderno de estos cambios, transformaciones, acontecimientos y situaciones. La lengua, la cultura y la memoria son pilares esenciales de los proyectos de los Estados-nación para crear una nueva sociedad. La forma moderna de gobierno, el Estado-nación, utiliza la historia no sólo como medio de transmisión, sino también como medio de construcción de la identidad y la memoria. Este estudio examina los expedientes de tres nombres críticos del movimiento kurdo y los debates basados en la historia en sus juicios. Aplicando el análisis del discurso, el objetivo es mostrar cómo tanto el Estado turco como el Partido de los Trabajadores del Kurdistán conceptualizaron y utilizaron la historia como herramienta para "probar" y "refutar" en los tribunales. El argumento principal del estudio es que la ideología oficial utiliza la historia para probar y transmitir un mensaje al resto de la sociedad, mientras que los acusados la utilizaron como medio de protesta en función de la realidad histórica y no de la historia como ciencia. Los jueces utilizaron la historia para probar la inexistencia de los kurdos, mientras que los acusados implicaron la historia como forma de protesta contra la autoridad gobernante.

Palabras clave: Senderos; Historia; Partido de los Trabajadores del Kurdistán 


\section{Introduction}

Changes in history and its scholarship have been directly influenced by the upper changes from the Empire to the nation and people's transition into citizens. Contrary to the history of empires, in the new paradigm, history has turned into a nation-building tool and citizenship construction. In this sense, history has been used as a characterization tool in the hands of pawer to build the idea of "collective greatness." Although history has become a narrative of power in the construction of societies, it has also been used by the oppressed or common people to de-construct such characterizations of societies and disrupts the monopoly over the use of history in the name of power.

The transition and transformation of the people and the ruling power, starting from the 19th and throughout the 2oth century, introduced power in the nation-state and the people with a new identity and citizenship. In contrast to the past, which is shaped by battles between ruling powers, the last two centuries have witnessed conflicts between the ruling power and people alongside wars between nationstates. Such massive replacements have also changed how history is constructed and how it is written from an analysis of the major shifts and war to the new set of tools and aspects of human history by taking on a more detailed approach. In this new writing, history does not solely rely on the investigation and presentation of the "facts" and mega occurrences, but it also gives massive attention to daily life, education, ideology, and mobilization.

Ancient people and historians adopted a different approach for understanding the source and the nature of law. They accepted that the source of law was God (Verhoeven, 2009, p. 90). Although the law refers to the order, that is, a settled system, it does not necessarily imply "good order" (Verhoeven, 2009, p. 90). The importance of the law for history lies in the understanding that people's actions are determined by the law or that people avoid attempting to break the law. As it provides a historian with information on the prevalent ideas and realities, the law can be considered a picture of a given place, society, and time (Verhoeven, 2009, p. 93).

Although court files have a long history, they have become a dominant source for the historical investigation of modern society in the $2 \mathrm{O}^{\text {th }}$ century. Court files that emerged in the late middle ages had two essential features: firstly, they represent the jurisdiction over crime and punishment; secondly, they allow researchers to track individual crimes and cultural traces (Verhoeven, 2009, p. 93). What is significant here is that modern court files include different sources such as testimonies, speeches, interrogation records, and due to their significance, they provide historians with an impression of the popular culture of a given period (Verhoeven, 2009). There has been a rise in the popularity of the micro-story. Micro-history focuses on individual behaviors and attitudes, which leads contemporary historians to study court files as primary sources. Therefore, "The historian might look at history through the law instead of looking at the law through history” (Verhoeven, 2009, p. 90).

Although the debate on whether history is a science ended a long time back, the debates and disagreements over the writing and usage of history are not over. Before the advent of nation-states, history, which was mostly aimed at recording, remembering, and transmitting, was sometimes a storytelling tool and sometimes involved a transference of traditions. Especially since the beginning of the 2oth century, the nation-state, which has risen as a new form of government, has turned historiography and the narrative of history into an ideological device and used it to create an identity to make people either forget or remember "things." This has transformed and changed the use of historical science and writing, which is now also used as a legitimization tool, as will be discussed in this article. Using history as a tool of validation and legitimation of an event, action, or policy is the most striking use of the social sciences by one of the nation-state's most complex systems.

In the last century, court files, judges, and legal documents related to crime and punishment have been among the most used by historians to identify laws and their implementation in a broader context (Dias Paes, 2019, p. 54). Some have argued that contrary to the past, the law was an order of god; later, such an approach facilitated the maintenance and legitimization of power (Dias Paes, 2019, p. 54). Such elaboration leads post-modernist historians in specific to argue that among social sciences, legal documents are both the constructed and produced tests of power and a means of shaping and defining boundaries of social actors and agencies (Hull, 2012, p. 341). The literature that describes the roles of files and legal documents, 
in general, holds that such paperwork is a bridge between reality and power and between society and order. These documents represent the relationship between power and society within the context of crime and punishment and facilitate the production of "truths" and the formation of reality. Most of these approaches are based on the belief that reality is constructed by the ruling authority, that is, the nationstate, and then shaped and re-shaped by it.

Although this approach, at first glance, gives the impression that history is left in the hands of the nation-state, it also indicates that history has also been the main legitimation and recall area for political movements and anti-colonial revolts in the second half of the last century. One of the most prominent examples of these two different but mutually reinforcing uses of history is the case files and discussions on history in courtrooms. The most important reason for this is the defendants who fight and refuse all these are against the judges who are the symbolic, powerful displays and judges of the state. This study aims to examine the Kurdish movement's members' case files (Kemal Pir, Mazlum Doğan, and Hayri Durmuş) as an example of the use of historical narratives in courtrooms that were, in fact, conflict arenas.

As a remnant of the former Ottoman Empire in the post-World War I period, the Turkish state began one of its most significant projects based on a deep and long-term Turkification project, aimed at the creation of the Turkish nationhood and transformation of all areas of politics and society. As the largest ethnic group, the Kurds in Turkey became one of the project's most significant obstacles due to their ethnic and linguistic differences from the Turks. The Kurds in Anatolia, who repeatedly revolted against the Turkish state, reached their most ideological phase by the time of the declaration by the Partiya Karkeran Kurdistan (PKK) in 1978 (Gürbüz, 2014)

One of the most obvious and striking ways of demonstrating how history is used to prove and justify is the lawsuit of these people who became symbols of resistance in the Kurdish movement history. As will be discussed below, while "the suspects" invoked history to prove the Kurdish existence, the judges and attorneys followed the Turkish history thesis and official history writing, which is based on the denial of the existence of Kurds in history and the indoctrination of Turkish supremacy. As can be understood, thousands of case files have been made on the armed conflict that has been going on since 1978 between the PKK and the Turkish state; however, this study examines the case files of three crucial names, both because of its reflection on the founding period of the PKK and their lasting impact on the Kurdish political movement.

\section{Method}

This case study applies discourse analysis to evaluate how and in which context both the judges and defendants used history in their debate. As language is a transmitter of ideas and argument as well as being a display of power and protest, to understand the import of the discussions during the trials, it is fundamentally crucial to diagnose how and to what extent history was implied as a means of proof and disproof.

This study aimed at examining the history-based debates on Kurdishness and Kurdistan by looking at the court defenses of three significant members of the PKK in the early 1980s. Applying discourse analysis, the documents were critically reviewed to underscore and highlight how some officials and the three suspects perceived and used history to buttress their arguments. The three names in question have become symbols of resistance both in the Kurdish Movement and in the memory of the Kurds. The three names analyzed in the study were deliberately chosen. The reason for this was that their defenses had become a reference in all the documents of the PKK and its recent historical memory. Knowing that the resistance was built on these three names, it became imperative to examine the court defenses of these names in terms of history-showing the PKK's perception of history. The main reason for applying discourse analysis as a method was to point out in clear terms how the judges and PKK members perceived history as a science and memory in the discussions that occurred during the trials. Furthermore, the focus was on conversations that included words such as history, Kurdish, and Kurdistan. Conscious of the value of discourse analysis, which evaluates the meaning, purposes, and conceptualization of any given topic, the target was to thoroughly demonstrate the subtexts of the discussions in courtrooms. 


\section{Background}

The PKK, which in Kurdish means the Partiya Karkeran Kurdistan, that is, the Kurdish Workers' Party, has been in an armed conflict since their first major attack in 1984. The PKK used force to demand that Turkey accept Kurdish ethnic rights and build a separate Kurdistan, and thus, has been deemed a "terrorist organization" by the UN, NATO, and the EU (Aytekin, 2019). The Kurdish conflict, which might be traced to the late Ottoman-era, has been one of the central debates studied in different fields of social science (Bruinessen, 2004). Due to the dissolution of the Empire, the Kurds' existence in Anatolia has become one of the country's and the region's major problems. Even though the problem has been framed within the national security framework and discourse, since the 1990s, Kurdish scholarship has moved to a broader context that includes democratization and ethnic and human rights. The Kurds in Turkey, who have been subjected to the massive Turkification project and Ataturk's top-to-bottom revolution, were the main obstacles to the creation of a less diverse Turkish nation. Due to their geographical consolidation and the size of the population in the early republican period, the Kurdish rebellion was mostly reflective, mainly shaped by the reaction to the centralization of power. They were against the idea of building a nation on the pillars of Sunni Islam and Turkishness. Additionally, the Kurdish rebellions were more local and traditional and had no ideological basis. The local rebellions, known as the Sheikh Said, Dersim, Koçgiri, and Agri, were typically less mobilized but resulted in massive displacements, killings, and the Turkification of the Kurds (Olson, 1989).

From the beginning of the 1960s, leftist ideology became extremely popular among intellectuals, activists, and students in big cities such as Istanbul and Ankara. Due to the influence of the national salvation movements and the 68 generations, the Turkish left, which was the main title of the leftists, received major support from the public. The Turkish Workers' Party won seats in the parliament (Lüküslü, 2015, p. 31) The left in Turkey considered the Kurdish problem as an "eastern problem" and organized several rallies and activist protests for a couple of years. The Kurds who mobilized under the Turkish left's roof since the 1960 s also conceptualized the Kurdish problem as an issue of economic inequalities and regional gaps in terms of modernization and industrialization (Güneş, 2012, pp. 49-64). Even though the left, in general, became quite popular among the intellectuals and public with the coup in 1970, the Turkish Workers' Party was banned by the state, and most of the Kurdish students and activists were imprisoned, including the leader of the PKK, Abdullah Ocalan (Joost, Akkaya, 2012). By looking at the people who were arrested and persecuted, who were mainly from the left-wing, it might be argued that the coup in 1970 was against the rise of the left, and after the coup, a colossal fragmentation occurred within the left and the Kurdish group that was led by Ocalan, which attempted to conceive an agenda for an independent Marxist-Leninist Kurdistan (Yavuz, 2001, pp.9-11)

The PKK's members whose court files will be analyzed established the ideology and agenda of the PKK in the 1970 (Casier, Jongerden, 2010, p. 131). The Turkish state's ideology, which was based on characterizing itself as a dependable western ally, considered the left as a threat of communism, and most of the files in that period had undertones of anti-communism and leftism. The Kurds, who founded the PKK on the Marxist-Leninist ideology theory, became a so-called danger because of their leftism and their new interpretation of the eastern problem. The PKK, in contrast to the Turkish left, defined it as a problem of freedom and colonization and tied to the demand for a separate Kurdistan, which was the basis of the trial and construction of the crimes.

With the rise of industrialization and the leftist ideology's impact, Kurdish students and activists were aligned with the Turkish left until the beginning of the 1970s. The PKK, which aims to free Kurdistan from the Turkish states, started guerrilla warfare against the Turkish in the early 1980s (Yavuz, 2001, pp. 9-11) The Kurdish movement's history shows that while before the 1960s, the Kurdish leaders who rebelled against the Turkish state were less educated and strictly traditionalist, the Kurdish who were mobilized from the early 1960 s were well educated and progressive in their claims and criticisms. In addition to this, the rebellions before the PKK were a reaction against republican centralization and nationalization reforms; however, the Kurdish intellectuals and activists in the 1960s and 1970s were more ideological activists influenced by the Marxist-Leninist theory (Gürbuz, 2016). In this period, the Kurdish mobilization not only claimed the independence of Kurdish regions through an armed struggle but also set up a fundamental historical-theoretical agenda for the PKK's aim. The science of history and memory for them was a way 
to prove the colonial history of the capitalist and colonialist Turkish state and legitimize a free Kurdistan's right.

Like all nation-states, the Turkish state and its founding elites gave vital importance to historiography and history writing. Ataturk's revaluation that aimed to build a unified Turkish nation in practice used history and language as a glue to unite people and prove that the only actor in politics and society was Turkishness. For these purposes, shortly after the Republic's foundation, the founding elites established the Turkish History Institution and Turkish Language Institution. In contrast, the former aimed to build and rewrite Turkish history and demonstrate how "ancient" and "magnificent" the long Turkish history was. It was a strictly nationalist history writing that excluded the Ottomans. The second one was established to simplify the Turkish language and purify it by ridding Arabic and Persian words from it.

The Turkish History Thesis is based on the idea that the Turks migrated from central Asia to different geographical territories; they also spread civilization (Doğan, 2013, p. 83). As one of the requirements of creating a new nation, based on the idea of the "best" and the "oldest," the Ottomans were excluded, and the focus was on the different dimensions of the Turkish states established before the Ottoman Empire. This understanding of history that emphasizes that the Turks are superior people is one of the examples of "racist" and social Darwinist conceptions at the beginning of the 2oth century. The founding elites of the new state, especially Atatürk, emphasized that Turks should be considered equal to westerners and claimed that Turks belong to the "yellow race," that is, Turks are also European (Cagaptay, 2006, p. 54). Such an understanding, which can be regarded as the mission and vision of the Turkish History Institution, is demonstrated in the book entitled Turk Tarhinin Ana Hatları or Mainlines of Turkish History, which was later studied in schools for years (White, 2014, p. 24) The official history, the study and writing of which was facilitated by the intellectuals of the era, also stemmed from the understanding of the "solar language theory" (Uzer, 2016, p. 102)

History and its practical uses in society's creation were indoctrinated on each level of education because the new generation should be reformed under the Turkishness and its history. In the Kurd's case, the official discourse was clearly founded on denying Kurds' very existence as an ethnic, linguistic group.

The defenses of the arrested PKK's members and their sympathizers in courtrooms are not merely an evaluation of the crimes committed or believed to be committed by them, but also a description of the problem. Such an assessment also helps better understand the construction of the state, PKK's problem, and the ideology and philosophy of the Kurdish movement. Even though there have been thousands of cases against the Kurdish movement and its members, the three cases that have been chosen deliberately are at the center of the construction of the Kurdish movement's memory. These three men, who died after their court trials, became symbols of resistance and created a wave of anger and revenge in the Kurdish movement and among the young Kurdish generation.

All the newspapers and books published by the PKK continually present these names in the context of martyrdom, resistance, and memory. However, these files' importance for historical investigation is that they show how the state and its institution conceptualized "crime" and how history is used as a tool for both suspects and the judges. As will be presented in the following pages, the courtrooms at one point became the "showground" for history and contra-history. While the former might be understood as the history of peoples and events and its science, contra-history, on the other hand, disturbs any claim by using and degenerating the usage of history. The defenses that will be demonstrated have been placed within the framework of the "concept case." The main contribution of this article to the literature, which has been mostly focused on the victimization of Kurds and the conflict between the state, PKK, and by the end of the 1970s, the court, judged not just a group of bandits but the Kurds as a nation using a historybased argument in contrast to previous studies.

The members whose files have been analyzed in this chapter died shortly after their court trials. Mazlum set himself on fire on March 21, 1982, Kemal Pir perished due to his fast unto death, and Hayri was killed in the same way on September 12, 1982, in prison. Their files have been a symbolic phase in the Kurdish movement's history, which has constructed a legacy of anger around them and takes one of the most significant steps toward forming post-mortem ideology. In the courtroom, the Turkish state was faced with its most considerable paranoia and threat, which later became a bloody war. Mazlum's sister, in an 
interview, said, "The authorities used to say they were 'a handful of bandits,' but now they have turned into a movement of millions" (ANFNEWS, 2015). The trial created a wave of societal anger, and girls and boys dreamed about emulating the feats of Mazlum, Kemal, and Hayri.

\section{The Usage of History in Courtrooms}

Traditionally, the Turkish History Thesis and official history writing have been shaped by the assumption of the rejection of the Kurds as a distinctive ethnic group and on the belief that everyone is somehow Turkish. Such denial-based understanding, which was put forward in different ways in different periods, dominated academia, press, political debates, and judicial hearings. Although much of the existing literature on the PKK and the Kurdish movement has not paid attention to examining the court files yet, as discussed above, judicial documents expose some of the most crucial aspects of the debate regarding the history and how it has been understood.

As a part of a political movement, the PKK's members hold the idea that streets, publications, and the courtrooms were arenas for explaining their ideological identity and confronting power (Orhan, 2012, p. 113). Such a pragmatic approach has been seen in all the hearings that this paper has analyzed. For instance, Kemal Pir, ${ }^{1}$ at the beginning of his hearing, answered a question by saying; "I like to answer these questions in front of history. Besides, I believe these courts are historical, that means it is not just a court for simple crime; it has historical importance" (Pir, 1981).

What this answer demonstrates is that for Pir, the court and the hearing were not considered a place where crime and innocence were investigated; it was a historical setting in which subjects and the power came to face to face, and the subject in a way aimed to turn memory into history, which will be written later. Similarly, his answer shows that in his view, the "recorder" and "transmitter" features of history were both an emphasis of the importance of the case and the transmission of the "message" to future generations.

Pir's use of the word Kurdistan in his speech created a debate between him and the judge, and the judge asked him where Kurdistan is and what its borders are by arguing that there was no place named Kurdistan and people who were Kurds. Following such a "historical reference," Pir stated, "We need to investigate Kurdistan and Kurds' history." The relation of the bourgeois class with Kurdistan was described in the context of class and capitalism in society and then as a nation; for them, Kurdistan was an example of this. In the case of the Kurdish language and its relationship with the border, he said, "The territory that the language spoken in is the border and territory of that nation. However, the political border might be different" (Pir, 1981). Like Pir, Mazloum Doğan² expressed that the structure and the actions of the court and law can be defined as the dominant class's superstructure. Furthermore, that is why he and his friends defend themselves not for the court and the accusation against them but for history. He said: "I feel responsible for historical facts" (Doğan, 1981).

For decades, Kurds' and Kurdistan's names were taboo, and the use of Kurd-related words was criminalized due to the so-called threats of "separatism and terrorism." (Özcan, 2006). Although the official discourse refers to the mostly Kurdish-populated regions as "east and southeast," their name has been Kurdistan for the Kurdish movement. During the hearings, the Kurds and the Kurdistan name were among the topics that lead to a heated discussion between the defenders and the judges. Much of the debate during Doğan's hearing was on the Kurdish language and Kurdistan as a geographic entity, and he argued for minutes on how the state had been putting pressure on Kurdish-populated areas in terms of culture, language, and economy (Doğan, 1981). For Doğan, the Turkish state had aimed to build the Turkish nation within the border of "Misaki-i milli" and assimilate minorities who contradicted its aim.

The questions related to Kurd and Kurdistan's name for Doğan were "useless, and empty discussion." (Doğan, 1981). The debate itself for him was proof that the Kurds and Kurdistan existed, and by playing

\footnotetext{
Kemal Pir, one of the prominent names of the PKK, who joined the party in 1976, and died after his fast unto death in Diyarbakir prison after he was arrested in 1980. Therefore, July 14 is known as Memorial Day, and he is still one of the influential and symbolic figures of the Kurdish political movement (Mavioglu, 2006).

${ }^{2}$ He was one of the founding members of the PKK, and he was arrested in 1979. On March 21, 1982, he committed suicide to protest the inhuman conditions of the prisons (Günes, 2012)

${ }^{3}$ Misal-I Milli, the national oath or/and national pact, is the lists of decisions made by the last Ottoman parliament and published on February $12,1920$. The oaths are centrally based on the borders of Anatolia (Turan, 1992, pp. 89-90).
} 
with words, he asked, "If there are no Kurds and Kurdistan, why did the PKK not occur in 1900, 1945, 1950, and even the 1960s?" (Doğan, 1981). Irony and, sometimes, simplicity were used as a strategic tactic to critique the court and their questions. Doğan and his friends were aware of the difference between "ordinary" crimes and political crimes. While the former one was more direct and had a clear-cut structure based on facts and testimonies, the latter, however, is an invented crime defined by the ruling powers, and the fight against the hegemony of the ruling power directly refers to such an invented crime. Doğan stated, "All these people are in this court not for stealing a horse or a donkey. They are here for a political reason" (Doğan, 1981). The political reason he mentioned was not just the state's ideology and its courts' but the demands of a group on behalf of the Kurds. Moreover, even though the states repeatedly refused that there was no Kurdish problem but "terror," in fact, as he said, "When the time comes, you cannot escape from it" (Doğan, 1981).

The existence of Kurdish as a language has always been a debate in Turkish politics and society. There is no mention of the language at departments of linguistic or literature at universities even today. Therefore, for the court, the aim was to prove that there was no Kurdish language, and it was made up of Arabic, Turkish and Persian. As per the source- and proof-based approach, one might argue that for the court to talk about a word's existence, they must have knowledge of linguistic research. Replaying such a point of view, Durmuş said, "We understand each other very well. Here you bring people from thousand kilometers to understand us. They can understand each other very well despite the aim of the destruction of the language" (Durmuş, 1982).

Concerning the debates on the Kurdish language, it is found that while the judges held the idea that a language should be "pure" and should not be derived from other languages, the defendants, as Doğan claimed, believed that "the origin of the language is not as important, as it can be argued that that in Latin America, several countries speak Portuguese, Spanish. Speaking these languages is not an obstacle for them to be a nation" (Doğan, 1981). It seems that for the judges to call a group a nation without an "original" language, the possession of a "great" history was essential, including the establishment of states in the past. When Doğan was asked whether the Kurds had founded any empire or state in history, Doğan gave the example of the Meds (Doğan, 1981).

As the hidden agenda was not to judge them but to judge the idea of the movement and the existence of Kurdistan, each time they used the words of Kurd and Kurdistan, they were asked if they knew history. The aim was to first create chaos in their minds by asking them specific questions such as "Did you analyze history?", "What were the sources?", and "Who wrote that text?" and show how "scientifically evident" it was that there were no Kurdistan and Kurds. However, the party members in the courtroom were not illiterate; on the contrary, they knew about history, politics, and how to use them. Historically and traditionally, the official discourse of the state has been formed by the belief that there were no Kurds, the Kurdish language, and a geographical terrain called Kurdistan. Further, the denial generated much disdain, such as the sound made when walking in the snow, "kart kurt." As the representative of power and the authority that held the tool to display the ruling power's strength, the judge asked Durmuş why he made up things such as the nation of the Kurds without any historical investigation. For the judge, the existence of the Kurds, their language, and their place in the historical investigation should prove things, and Durmuş ${ }^{4}$ responded in the following manner: "Let me say this. When I said I do not have the information, I did not mean I do not know; what I said was I am not a historian. Of course, I read several books and documents" (Durmuş, 1982).

Another question on the Kurds' origin followed this, after which questions on where the Kurds came from and the source of such information were asked. In response to such "scientific" and proof-reliant question, Durmus said, "Each nation does not look at the stones, printing, or stamped paper when they are born or claim their history. Many documents can be found in the of historian's diaries and travel notes about the Kurds and Kurdistan" (Durmuş, 1982).

Given the questions asked by the judges and the answers given by the defendants, one might claim that while the ruling authority held the idea that history must be evidence-based and without so-called evidence,

${ }^{4}$ Mehmet Hayri Durmuş, who attended the founding meetings of the PKK and took part in the preparation of the party's program draft, died on the 55th day of his death fast, like his other friends. More information on his life can be found at: http://www.medyahaber.info/mehmet-hayri-durmus-14temmuz-direnisinin-kadrosu/ 
the existence of a language, geography, and a nation cannot be discussed, the "suspects" believed that the central and most significant indications are the political, sociological, and economic reality that they lived in.

\section{Discussion}

In the courtroom, the suspects, including Durmuş, were supposed to be a "linguist," a "historian," and a "terrorist." Even though they were in the courtroom for "terrorism," they fought with the judges over the past and the majoritarian mentality, and that is why in those rooms, history was on trial, not them. What do these questions and answers, the words used, and the arguments put forward mean? Considering the answers to this question from the judges and the defendants' perspective, an interpretation can be made as follows.

When we look at the judges' arguments and discourses, a distorted approach emerges, that history is seen as a definitive means of proof, and therefore, one cannot speak of the existence of a language, a geographical region, and more importantly, a nation without historical sources. The judges, who are the official representatives of the Turkish nation-state, put forward the state's official historical thesis and denied the existence of a nation called Kurds. The judges' claim that Kurdish is the sum of other languages aligns with the aims of institutions such as the Turkish Language Institution and the Turkish Historical Institution, which are the homogenization tools of the new state, and shows that this understanding is reflected by the law, which, in this case, has been turned into official historiography.

From the point of view of the accused, a more protest-related perception of history emerges. For them, history is both a rejection of the state's understanding and its ideological tools and a means of building political memory. Likewise, while presenting historical proof of the Kurdish existence, the defendants drew attention to societies and individuals' variability according to periods and conditions. Beyond these different uses of history, the point that should be emphasized is how the judges and prisoners used courtrooms. While the defendants used the halls as a protest area, a continuation of the events on the streets, the judges approached it as a place of warning for the detainees and a means of demonstrating the state's power to both the left and the Kurds.

\section{Conclusion}

In the modern sense, the nation-state uses the courtroom as an ideological apparatus to keep its hegemony by punishing threats to it. In "sensitive nations" such as Turkey, the location is not only a site for the confrontation between the ruling power and the subject but also history and contra-history, as by turning a courtroom into a stage gives rise to the notion that political crimes are not individual but societal.

The defenses that have been analyzed above show how the nation-state, Turkey, and a political movement, the PKK, apply history not just as a science but more frequently as a weapon against one another. The trials' importance lies in the confrontation of history and contra-history represented by these two opponents. As it has been argued, the court was a tool, and while for the court, it was an opportunity to show the consequences of being an "enemy" to the system and using history to disprove the movement, the defendants employed it as a tool to propagate their personal history and the ideology of the party that they believed would change the system. What is significant in these files is that their defenses disprove the Kurdish movement's approaches regarding nationalism, violence, aim, and strategies. Although there had been several cases in Kurdish history that ended with the activist being punished with the death penalty or imprisonment, for the first time, a nation and its existence were on the trail. While before the PKK, "the bandits and a handful gangsters" were persecuted and named terrorists and separatists, the Kurds as a nation who had political demands were on trial this time. The findings of these files demonstrate the official discourse and the state's ideology. For the state, the Kurdish language and Kurdish existence have been a matter of denial, which has been systemically indoctrinated via its national education, media, and politics.

The irony the title refers to lies in a double-edged interpretation of history. The judges, who were aware that there had been a movement aimed at building an independent Kurdistan for the Kurds, put not only these three men on trial but also their ideologies and the Kurdish identity. The official discourse based on the denial of the existence of the Kurds as an ethnic-linguistic community led the judges to put the 
defendants in a position to prove that they did exist. Although it is doubtful whether they convinced the authorities in the room about their existence, their trials and political struggle that ended with death have left an indelible mark on the Kurdish movement and the Kurds till today.

\section{REFERENCES}

Aytekin, M. (2019). Radicalisation processes of the Kurdistan Workers Party (PKK): ideology and recruitment tactics. Journal of Policing, Intelligence and Counter Terrorism. 14(1). 62-81. https://doi.org/10.1080/18335330.2019.1572912

Cagaptay, S. (2006). Islam, secularism, and nationalism in modern Turkey; who is a Turk? Routledge.

Casier, M \& Jongerden, J. (2010). Nationalisms and Politics in Turkey: Political Islam, Kemalism and the Kurdish Issue. Routledge.

Dias Paes, M. A. (2019). Legal files and empires: Form and materiality of the Benguela District Court Documents. Administory, 4(1), 53-70. https://doi.org/10.2478/adhi-2019-0004

Doğan, M. (1981, June 18). Mazlum Doğan'nın siyasi savunması. SARA Distribution. https://www.saradistribution.com/ mazlum_dogan_savunma.htm

Durmuş, H. (1982, June 14). Mahkeme tutanaklarından PKK davası. SARA Distribution. https://www.saradistribution. com/hayri_durmus_savunma.htm

Güneş, C. (2012). The Kurdish national movement in Turkey: From protest to resistance. Routledge.

Gürbüz, M. E. (2014). Ideology in action: symbolic localization of Kurdistan Workers' Party in Turkey. Sociological Inquiry, 85(1). 1-27. https://doi.org/10.1111/soin.12066

Gürbüz, M. E. (2016). Rival Kurdish movements in Turkey: transforming ethnic conflict. Amsterdam University Press.

Gürpinar, D. (2013). Ottoman/Turkish visions of the nation, 1860-1950. Palgrave MacMillan.

Hull, M. S. (2012). Government of paper: The materiality of bureaucracy in urban Pakistan. University of California Press.

Jongerden, J.P. \& Akkaya, A. (2013). The Kurdistan Workers Party and a New Left in Turkey: Analysis of the revolutionary movement in Turkey through the PKK's memorial text on Haki Karer. European Journal of Turkish Studies. https://doi.org/10.4000/ejts.4613

Lüküslü, D. (2015). Türkiye'nin 68'i: bir kuşă̆ın sosyolojik analizi. Dipnot Yayınları.

Olson, R. W. (1989). The emergence of Kurdish Racism and the Sheikh Said Rebellion, 1880-1925. University of Texas Press.

Orhan, M. (2015). Political violence and Kurds in Turkey: Fragmentations, mobilizations, participations and repertoires, Routledge.

Özcan, A.K (2006). Turkey's Kurds: a theoretical analysis of the PKK and Abdullah Ocalan. Routledge.

Pir, K. (1981, May 28). Mahkeme tutanaklarından PKK davası. Kurdipedia. https://www.kurdipedia.org/files/ books/2012/65670.PDF?ver=129895801345811176

Turan, Ş. (1992). Türk devrim tarihi. Bilgi Yayınevi.

Uzer, U. (2016). An intellectual history of Turkish nationalism. The University of Utah Press.

Van Bruinessen, M. (2004). The Kurdish movement: issues, organization, mobilization. On the Waterfront, International Institute for Social History, 8, 10-12

Verhoeven, C. (2009). Court files. In, Dobson \& B. Ziemann (Eds.). Reading primary sources, the interpretation of texts from nineteenth and twentieth-century history (pp.90-105) Routledge.

White, J. (2014). Muslim nationalism and the new Turks. Princeton University Press.

Yavuz, M. H. (2001). Five stages of the construction of Kurdish nationalism in Turkey. Nationalism and Ethnic Politics, 7(3), 1-24. https://doi.org/10.1080/13537110108428635

ANF. (2013, May 20). Mazlum Doğan in his parents' words. ANFNEWS. https://anfenglish.com/news/mazlum-dogan-inhis-parents-words-6919

Medya Haber. (2019, September 12). Mehmet Hayri Durmuş: 14 Temmuz Direnişi'nin kadrosu. MedyaHaber. https:// www.medyahaber.info/mehmet-hayri-durmus-14-temmuz-direnisinin-kadrosu/

\section{AUTHOR}

Islam Sargi. PhD candidate, University of Szeged, Department of Contemporary History

\section{Conflict of interest}

No potential conflict of interest is reported by the author.

Funding

No financial assistance from parties outside this article. 